\title{
The Design of Arduino Uno Based Automatic Concrete Maker
}

\author{
Rangga Pradana Putra. D ${ }^{\mathrm{a}, 1, *}$, Yusli Yenni ${ }^{\mathrm{b}, 2}$ \\ ${ }^{a}$ Informatics Engineering Department, Universitas Putera Batam, Jl. R. Soeprapto Muka Kuning, Batam 29434, Indonesia \\ b Informatics Engineering Department, Universitas Putera Batam, Jl. R. Soeprapto Muka Kuning, Batam 29434, Indonesia \\ ${ }^{1}$ ranggacumi48@gmail.com*; ${ }^{2}$ yusliany10@gmail.com
}

\begin{tabular}{|c|c|}
\hline & ABSTRACT \\
\hline $\begin{array}{l}\text { Keywords } \\
\text { Arduino } \\
\text { Concrete } \\
\text { Loadcell } \\
\text { Motor shield } \\
\text { Otomatic }\end{array}$ & $\begin{array}{l}\text { Making concrete manually is very time-consuming and energy-intensive. And if ordering } \\
\text { concrete to the company can increase construction costs. The purpose of this research is } \\
\text { to make concrete automatically with materials that are in accordance with Indonesian } \\
\text { concrete standards so there is no need to order it again to the company. The tools used in } \\
\text { this design are arduino uno , motor shield, sensors loadcell, servo motor, dc motor, } \\
\text { solenoid valve, power supply, and button. The start button is connected to the pin on the } \\
\text { arduino, then arduino is connected to the motor shield after it is connected to the servo } \\
\text { motor, dc motor, loadcell, and the solenoid valve then given current by connecting the } \\
\text { power supply to the motor shield and motor servo. The performance of this tool starts from } \\
\text { pressing the button that matches the size of the concrete to be produced the the button } \\
\text { signal will send to Arduino and the motor shield after that from the motor shield the signal } \\
\text { is sent to the sand and rock servo motor, then it will be weighed with a loadcell sensor and } \\
\text { poured what has been weighed into the blender to mix evenly, then the signal sent to the } \\
\text { cement DC motor and solenoid valve to remove the cement and water to be mixed into the } \\
\text { blender. After the stirring process is complete, the signal will be sent to the blender servo } \\
\text { motor which will pour the concrete that has been processed. The design of the tool runs as } \\
\text { desired. }\end{array}$ \\
\hline
\end{tabular}

\section{Introduction}

The development of technology today is growing rapidly from a manual system into a computer and software system. So that it can help the work that was originally done by humans become done with the help of the computer to be automated by programming the computer and software. Currently in the construction of small houses to supply concrete, always order concrete or make it yourself with a non-standard size, Jobs that are done manually can be far more effective but the work automatically is very helpful and saves time and simplifies human work. And the problems that occur when mixing concrete manually can waste time and energy and the size of concrete classified as outside the standard size of Indonesian concrete[1], by making automatic concrete tools, it can do compounding concrete in accordance with the recipe that has been standardized right. This tool is equipped with a servo motor and a de motor to remove concrete material and a dc motor to run the blades and cement blades[2]. This tool is designed by using Arduino to move all components that exist.

\section{The Proposed Method/Algorithm}

\subsection{Arduino}

Arduino is an electric board that uses certain types of microcontroller. Ardino is a hardware output drom Arduino Italy, one of which is Arduino Uno, which is one of Arduino which is very common or very widely used to design automatic devices that need to microcontroller.[3]

\subsection{Microcontroller Atmega328}

Atmega 328 is a microcontroller output from atmel that has a RISC (Reduce Intruction Set Computer) architecture when every data execution process is faster than the other architecture, namely CISC (Completed Intruction Set Computer).[4] 


\subsection{Loadcell Sensor}

Load cell are a core component of digital scales. In general, Load cell is used to calculate the mass of an object. A load cell sensor is composed of several conductors, a strain gauge, and a wheatstone bridge.[5]

\subsection{Motor Shield}

Motor Shield is an Arduino Shield that is easy to use for the use of wheeled robot applications or many use motor type tools, such as DC motors and servo motors. The Motor Shield itself is capable of moving 4 DC motors and 2 servo motors at once.[4][6]

\section{Method}

\subsection{Hardware Design}

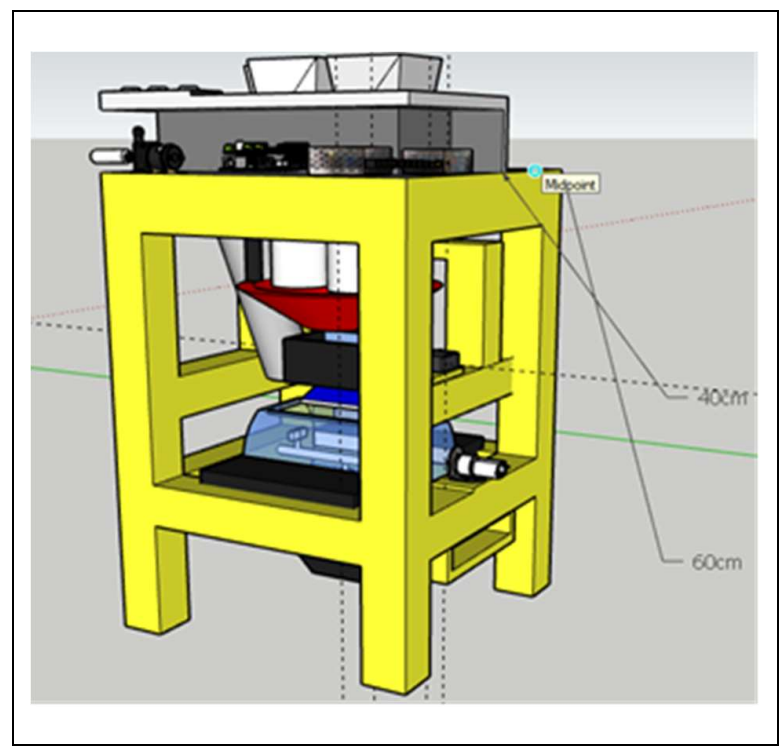

Fig. 1. Hardware Design

Hardware design is very important in the construction of tools, because at this stage there is an electrical circuit in order to reduce errors on the device. Hardware design show figure 1

\subsection{Electrivcal Device Design}

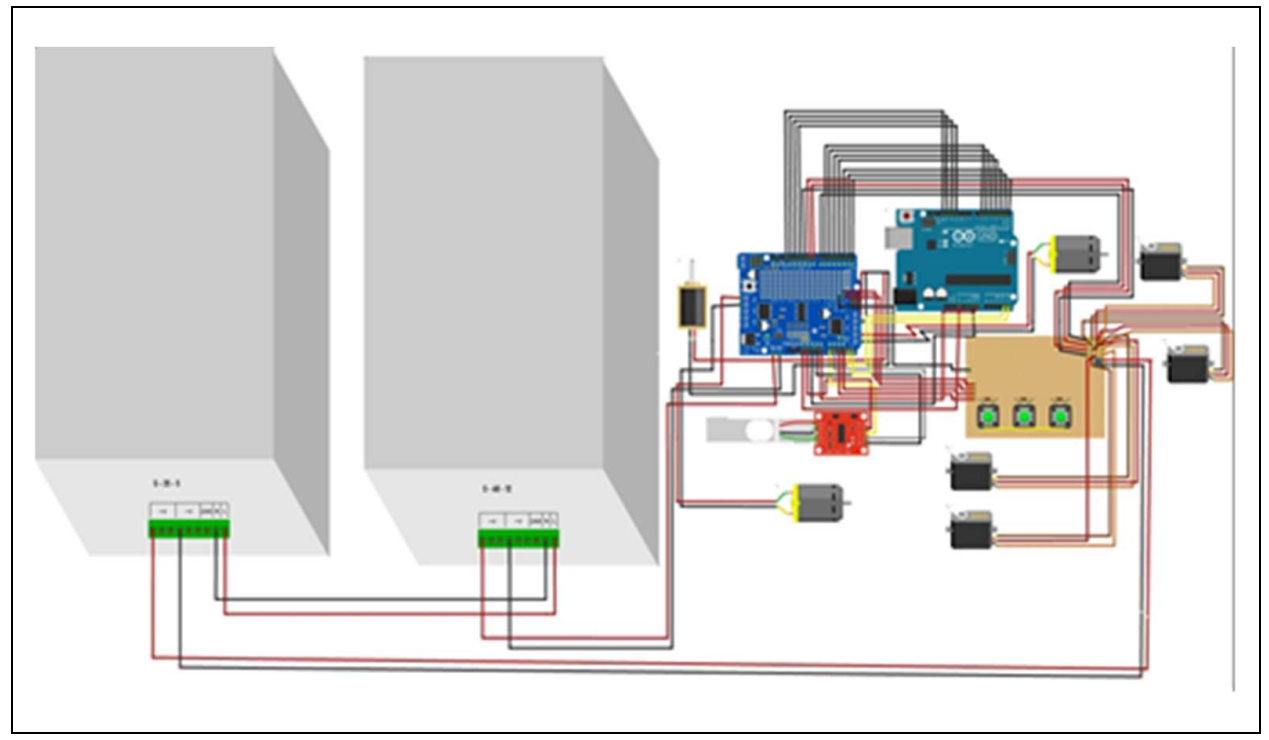


JEEMECS (Journal of Electrical Engineering, Mechatronic and Computer Science) ISSN 2614-4859 Vol. 3, No. 2, August 2020, pp. 171-178

Fig. 2.Electrical Device Design

Table 1. Electrical Device design

\begin{tabular}{clc}
\hline Name I/O & Type & Pin Allocation \\
\hline Button & Input & $A 1, A 0, G N D$ \\
Motor DC & Output & $5 V, G N D$ \\
Motor Servo & Output & $5 V, G N D, D 9, D 10, D 8, D 7$ \\
Load Cell & Output & $5 V, A 0, A 1, G N D, V C C, D A T, C L K, G N D$ \\
Solenoid Valve & Output & $5 V, G N D$ \\
Power Supply & Output & $V+, V-$ \\
\hline
\end{tabular}

\subsection{Flowchart System}

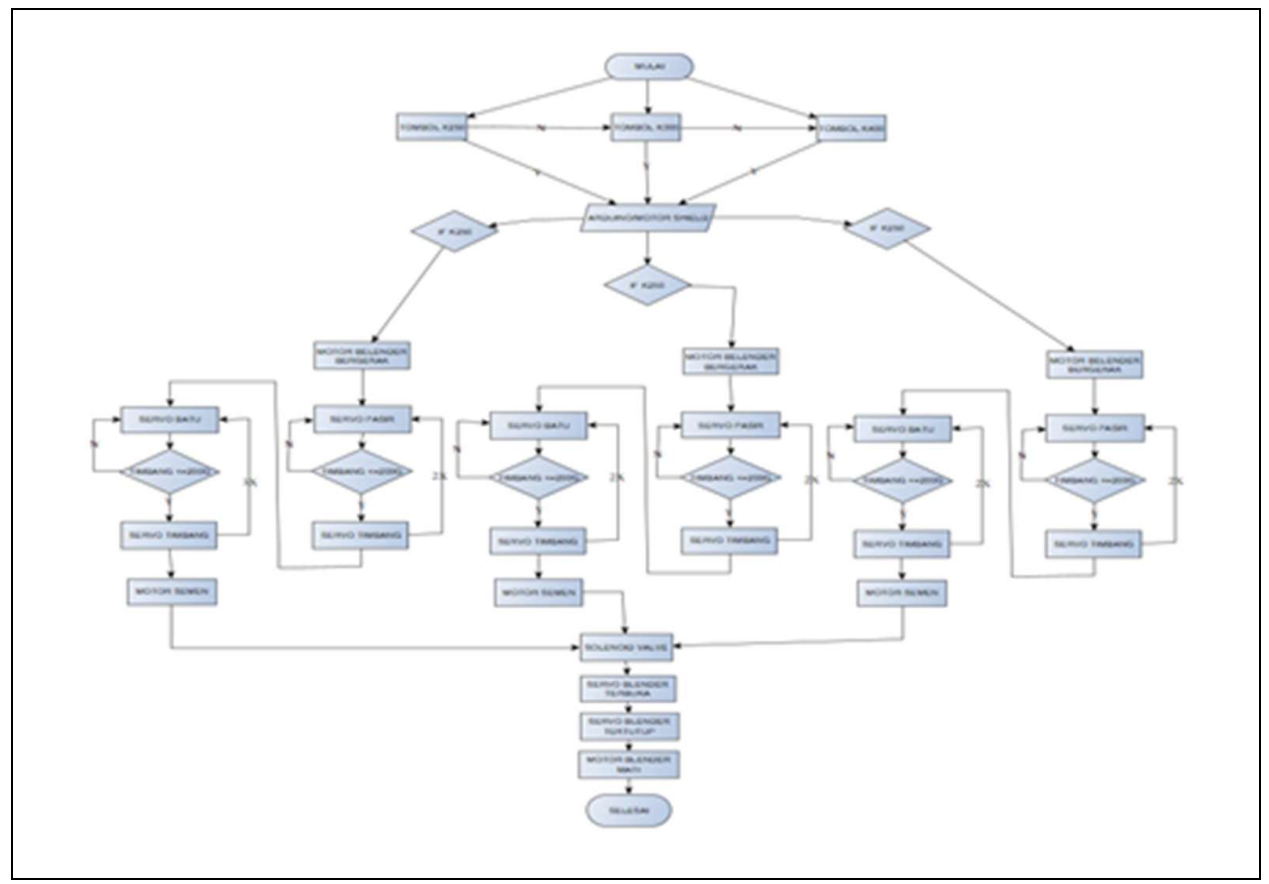

Fig. 3. Flowchart System

From the flowchart figure 3, it can be seen the working process of the tool being built. It starts by pressing one of the three buttons provided then the signal is sent to Arduino and the Shield motor, after which the signal will be sent to the DC belender motor and then proceed to the sand servo motor, if sand $\leftarrow 200$ grams the weighing process will continue 


\section{Results and Discussion}

\subsection{Tool Designing Result}

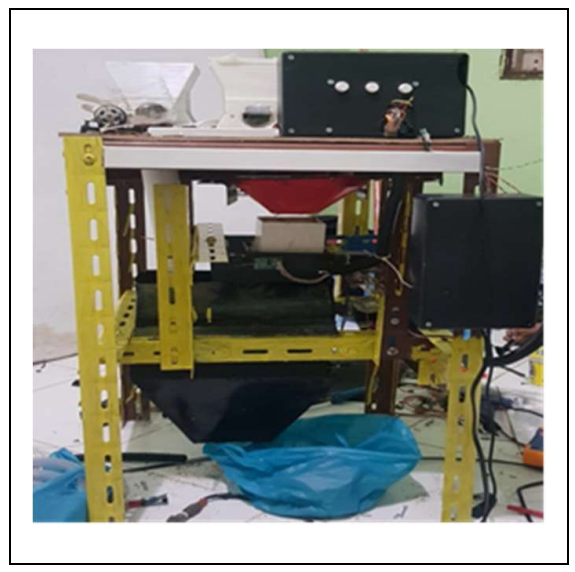

Fig. 4. Software Design

The figure 4 is the result of designing an automatic concrete maker that has been installed with all its components such as Arduino, motor shield, DC motor, servo motor, solenoid valve, loadcell and power supply.

\subsection{Software Design Result}

The result of software design on this tool system using Arduino IDE software. In this program contains commands to move the motor, buttons, and scale calibration. Show figure 5

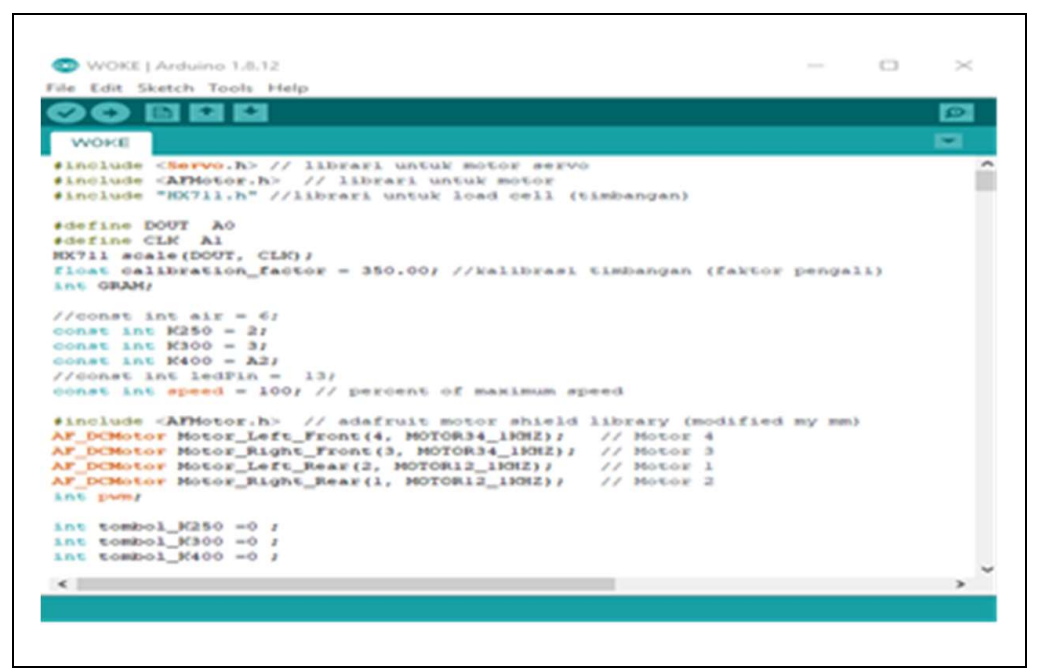

Fig. 5. Software Design

Furthermore, the picture below is a program for loadcell sensor calibration, because without calibration the scales will not fit, especially with the hanging position of the scales which requires periodic calibration, in order to get a fixed value. In carrying out the calibration, as well as first having to introduce with Arduino then enter the calibration value that is set to the pin that has been determined in the motor shield. Show figure 6 


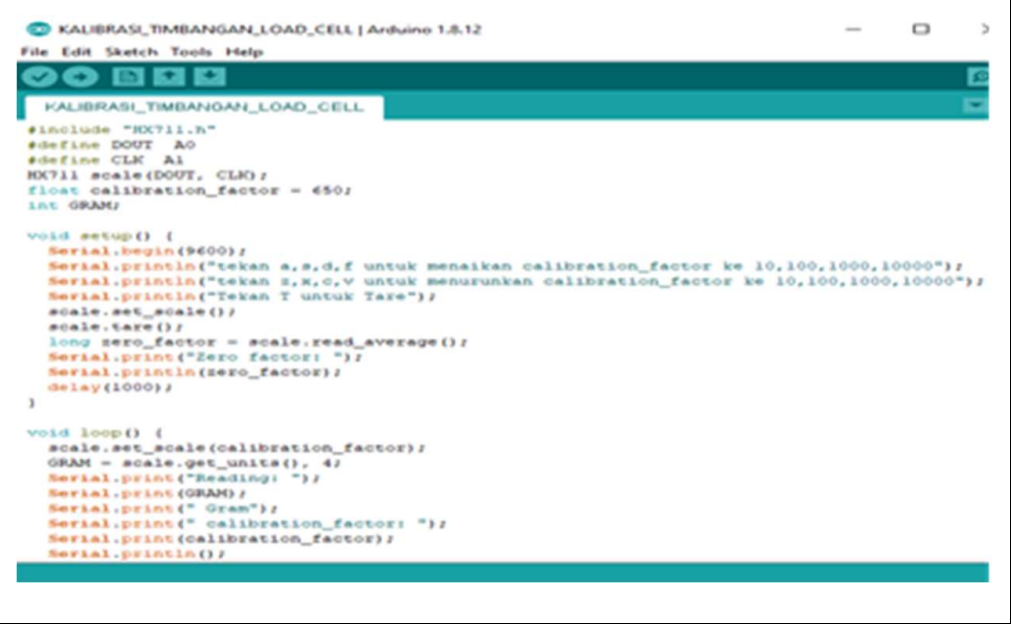

Fig. 6. Loadcell Sensor Calibration Program

\subsection{Testing Result}

After designing the automatic concrete making equipment, it is necessary to test the tool. Testing this tool aims to ensure this tool works properly, as expected. Especially in terms of the size of the material used, because this tool has 3 sizes.

\subsubsection{The Accuracy of the $\mathrm{K} 250$ Concrete}

This test is carried out to ensure the accuracy of the material from K250 concrete, because sand and stone are measured with a scale using a Loadcell sensor, this test is taken to ensure the tolerance size of each K250 concrete production.

Table 2. K250 Concrete Testing Result

\begin{tabular}{ccc}
\hline Activities & $\begin{array}{c}\text { Sand Size } \\
(\boldsymbol{g})\end{array}$ & $\begin{array}{c}\text { Stone Size } \\
(\boldsymbol{g})\end{array}$ \\
\hline Necessary Materials & 100 & 200 \\
First Production Test & 106 & 194 \\
Second Production Test & 98 & 210 \\
Third Production Test & 101 & 210 \\
Fourth Production Test & 100 & 201 \\
Fifth Production Test & 110 & 200 \\
Sixth Production Test & 100 & 201 \\
Seventh Production Test & 98 & 206 \\
Eight Production Test & 105 & 200 \\
Ninth Production Test & 100 & 205 \\
Tenth Production Test & 101 & 198 \\
\hline
\end{tabular}

From the test Table 2 the concrete material has a small size tolerance, meaning that the calibration of the scales and servo motor works well, as expected. So the tolerance obtained is $10 \mathrm{~g}$. then the K250 concrete test results are considered successful.

\subsubsection{Materials of K300 Concrete Accuracy Test Results}

This test is carried out to ensure the accuracy of the material from K300 concrete, because sand and stone are measured with a scale using a Loadcell sensor, this test is taken to ensure the tolerance size of each K300 concrete production.

Table 3. K300 Concrete Testing Result

\begin{tabular}{ccc}
\hline Activities & $\begin{array}{c}\text { Sand Size } \\
(\mathbf{g})\end{array}$ & $\begin{array}{c}\text { Stone Size } \\
(\mathbf{g})\end{array}$ \\
\hline Necessary Materials & 120 & 200
\end{tabular}

175 | P a g e 


$\begin{array}{ccc}\text { First Production Test } & 123 & 206 \\ \text { Second Production Test } & 125 & 201 \\ \text { Third Production Test } & 115 & 200 \\ \text { Fourth Production Test } & 120 & 205 \\ \text { Fifth Production Test } & 120 & 200 \\ \text { Sixth Production Test } & 128 & 201 \\ \text { Seventh Production Test } & 110 & 190 \\ \text { Eight Production Test } & 119 & 200 \\ \text { Ninth Production Test } & 121 & 200 \\ \text { Tenth Production Test } & 120 & 201\end{array}$

From the test Table 3 the concrete material has a small size tolerance, meaning that the calibration of the scales and servo motor works well, as expected. So the tolerance obtained is $10 \mathrm{~g}$. then the K300 concrete test results are considered successful.

\subsubsection{Materials of K400 Concrete Accuracy Test Results}

This test is carried out to ensure the accuracy of the material from K400 concrete, because sand and stone are measured with a scale using a Loadcell sensor, this test is taken to ensure the tolerance size of eacg K400 concrete production. Show table 4

Table 4. K400 Concrete Testing Result

\begin{tabular}{ccc}
\hline Activities & $\begin{array}{c}\text { Sand Size } \\
(\mathbf{g})\end{array}$ & $\begin{array}{c}\text { Stone Size } \\
(\mathbf{g})\end{array}$ \\
\hline Necessary Materials & 150 & $250 \mathrm{~g}$ \\
First Production Test & 156 & $252 \mathrm{~g}$ \\
Second Production Test & 148 & 256 \\
Third Production Test & 150 & 246 \\
Fourth Production Test & 155 & 250 \\
Fifth Production Test & 152 & 258 \\
Sixth Production Test & 150 & 246 \\
Seventh Production Test & 148 & 250 \\
Eight Production Test & 156 & 258 \\
Ninth Production Test & 150 & 250 \\
Tenth Production Test & 155 & 251 \\
\hline
\end{tabular}

\subsubsection{Servo Motor Testing Results}

This servo motor test is carried out so that it can monitor the performance of the four servo motors that are moving.

Table 5. Servo Motor Testing Result

\begin{tabular}{ccccc}
\hline Activities & Sand Servo & Stone Servo & Pour Servo & Blender Servo \\
\hline Production 1 & Succeed & Succeed & Succeed & Succeed \\
Production 2 & Succeed & Succeed & Succeed & Succeed \\
Production 3 & Succeed & Succeed & Succeed & Succeed \\
Production 4 & Succeed & Succeed & Succeed & Succeed \\
Production 5 & Succeed & Succeed & Succeed & Succeed \\
Production 6 & Succeed & Succeed & Succeed & Succeed \\
Production 7 & Succeed & Succeed & Succeed & Succeed \\
Production 8 & Succeed & Succeed & Succeed & Succeed \\
Production 9 & Succeed & Succeed & Succeed & Succeed \\
Production 10 & Succeed & Succeed & Succeed & Succeed \\
\hline
\end{tabular}

From the Servo Motor testing table 5 it can be concluded that the performance of the four servo motors is very good according to the instructions made through the Arduino IDE program. 


\subsubsection{Tool Success Rate}

The success rate of the tool is very important to see how successful the tool is made.

Table 6. Percentage of tool success for each production

\begin{tabular}{cc} 
Concrete Types & $\begin{array}{c}\text { Percenntage of Success } \\
\text { (\%) }\end{array}$ \\
\hline K250 Concrete Production & 95 \\
\hline K300 Concrete Production & 95 \\
\hline K400 Concrete Production & 95 \\
\hline
\end{tabular}

Numbers $95 \%$ of $100 \%$ obtained from the success rate of tools in producing K250, K300, and $\mathrm{K} 400$ concrete. The success itself is seen from the servo performance and the accuracy of the material that has been tested. From the accuracy of the material still requires a tolerance value of $10 \mathrm{~g}$, then the success rate of the tool becomes $95 \%$ because the accuracy of the material still requires still requires tolerance.

\section{Conclusion}

1. Based on the test result, this automatic concrete maker succeed in producing concrete with $\mathrm{K} 250$, $\mathrm{K} 300, \mathrm{~K} 400$ quality, even though it needs $10 \mathrm{~g}$ material.

2. By using this tool makes concrete making is much more effective and saves energy and costs.

3. from the results of the belender strength testing can be concluded. In the blender that is made is still not perfect, because there are still a lot of water leakage in the built blender.

\section{References}

[1] L. Rahmadianty, H. Mazaya, D. Purwanto, and R. Y. Adi, "Analisa Campuran Beton Dengan Perbandingan Volume Dan Pengamatan Karakteristik Beton Mutu Sedang,” J. KARYA Tek. SIPIL, vol. 6, no. 2, pp. 55-69, 2017.

[2] N. Suryangga, N. Nachrowie, and A. P. Sari, "Implementasi Metode Master Slave untuk Sistem Pengaman Sepeda Motor dan Helm," JEECAE (Journal Electr. Electron. Control. Automot. Eng., vol. 3, no. 1, pp. 151-156, 2018.

[3] E. D. Arisandi, "Kemudahan Pemrograman Mikrokontroller Arduino Pada Aplikasi Wahana Terbang," Setrum Sist. Kendali-Tenaga-elektronika-telekomunikasi-komputer, vol. 3, no. 2, pp. 114-117, 2016.

[4] A. Adriansyah and O. Hidyatama, "rancang bangun prototipe elevator menggunakan microcontroller arduino atmega 328p," J. Teknol. Elektro, vol. 4, no. 3, 2013.

[5] W. WAHYUDI, A. RAHMAN, and M. NAWAWI, "Perbandingan nilai ukur sensor load cell pada alat penyortir buah otomatis terhadap timbangan manual," ELKOMIKA J. Tek. Energi Elektr. Tek. Telekomun. Tek. Elektron., vol. 5, no. 2, p. 207, 2017.

[6] P. D. P. Adi and R. Arifuddin, "Design Of Tsunami Detector Based Sort Message Service Using Arduino and SIM900A to GSM/GPRS Module," JEEMECS (Journal Electr. Eng. Mechatron. Comput. Sci., vol. 1, no. 1, pp. 1-4, 2018. 
JEEMECS (Journal of Electrical Engineering, Mechatronic and Computer Science) ISSN 2614-4859 Vol. 3, No. 2, August 2020, pp. 171-178

\section{This page intentionally left blank}

